\title{
Use of Mono-Layer Preparations in Studies of Nucleolar Morphology in Pancreatic Islet Cells
}

It has been shown for a number of cells that the morphology of the nucleolus is intimately related to the rate of protein synthesis ${ }^{1}$. The increased insulin production characteristic for the obese-hyperglycemic syndrome in mice is, for example, reflected in larger nucleoli of the pancreatic $\beta$-cells as compared to normal controls ${ }^{2}$. Since known stimuli of insulin production seem to vary with respect to their effect on the synthesis of the hormone ${ }^{3}$, we have been interested in obtaining a simple and sensitive method allowing fast screening of various compounds for effects on the nucleolar morphology in islet cells. In the present study we have taken advantage of the facts that mono-layer preparations of endocrine pancreatic cells can easily be prepared by gentle squashing of isolated islets $\mathbf{4 , 5}$ and that the true number and size of nucleoli can be directly evaluated in such preparations. Islets of normal and obese-hyperglycemic mice were used as welldefined sources of $\beta$-cells with different protein-synthesizing activity.

Material and methods. Ten obese-hyperglycemic mice ${ }^{6}$ and 8 of their lean litter-mates were used. All animals were $8-9$-month-old females. After killing by decapitation and isolation of the pancreatic islets ${ }^{4}$, mono-layer preparations of the islet cells were prepared by gentle squashing on glass microscope slides $\mathbf{4 , 5}$. After drying at room temperature, the specimens were processed according to the following scheme: (1) fix in Lillie's buffered formol solution 7 for $30 \mathrm{~min}$; (2) wash in distilled water for $5 \mathrm{~min}$; (3) expose to $100 \mathrm{mM}$ lead nitrate for $15 \mathrm{~min}$; (4) wash in distilled water for $30 \mathrm{sec}$; (5) expose to $1 \%$ ammonium sulphide for $5 \mathrm{~min}$; (6) wash in distilled water for $30 \mathrm{sec}$; (7) dehydrate in absolute ethanol for $10 \mathrm{~min}$; (8) clear in xylol for $5 \mathrm{~min}$ and mount in Canada balsam.

The cells were analyzed in a phase contrast microscope using a total magnification of $\times 2000$. All observations were made by the same person, who did not know the identity of the specimens. The number of nucleoli was counted in 30 randomly selected nuclei from each islet. The relative nucleolar volume was estimated by point sampling ${ }^{8}$. For the determination of the nuclear diameter and the position of the largest nucleolus, 16 randomly selected nuclei in each islet preparation were analyzed with the aid of an ocular screw micrometer. The mean eccentricity ratio was calculated according to ERÄNKö ${ }^{8}$.

Results and discussion. The employed lead-treatment of fixed mono-layer specimens brought about a distinct outline of the nucleoli as revealed by phase contrast microscopy. As can be seen in the Table, the number of nucleoli per cell nucleus was significantly higher in the obese-hyperglycemic mice than in their lean litter-mates. This information was obtained from a rather small number of analyzed nuclei by virtue of the fact that all nucleoli could be directly counted in the non-sectioned cells. The relative volume occupied by nucleoli in each nucleus was also the highest in the obese-hyperglycemic mice. In fact this parameter most strongly reflected the difference in insulin-synthesizing activity between the 2 groups of mice. The result conforms well with previous demonstrations that the nucleolar mass is correlated to the rate of protein synthesis in cells ${ }^{1}$. It should be pointed out that the difference obtained in the present study is much greater than could be expected only because the islets of normal mice contain about $80 \%$ of $\beta$-cells, while the corresponding proportion in obese-hyperglycemic mice is about $90 \%{ }^{6}$. Although the nuclear diameter was found to be somewhat higher in the obese-hyperglycemic mice than in the normal litter-mates, the difference was not statistically significant with the small samples studied. Neither could any significant difference be shown with respect to the eccentricity ratio of the largest nucleolus. It may therefore be concluded that point-sampling of the relative nucleolar volume in mono-layer preparations of islet cells can be used as a fast and sensitive technique for detecting morphological signs of increased insulin synthesis in mice $^{9}$.

Zusammenfassung. Die Untersuchung an endokrin wirksamen Zellen der Bauchspeicheldrüse bei normalen und adipösen Mäusen ergibt eine relative Vergrösserung des Nukleolus der cndokrinen Zellen bej den adipösen Tieren, was als morphologisches Zeichen gesteigerter Insulinproduktion angesehen wird.

\section{I.-B. TÄLJEDAL and A. WAHLIN}

Department of Histology, University of Umea, S901 87 Umeå (Sweden), 18 June 1969.
Comparison between normal and obese-hyperglycemic mice with respect to nuclear morphology

\begin{tabular}{lllll}
\hline Animals & $\begin{array}{l}\text { Nuclear } \\
\text { diameter } \\
\text { in arbitrary } \\
\text { units }\end{array}$ & $\begin{array}{l}\text { No. of } \\
\text { nucleoli }\end{array}$ & $\begin{array}{l}\text { Eccentricity } \\
\text { ratio for } \\
\text { largest } \\
\text { nucleolus }\end{array}$ & $\begin{array}{l}\text { Relative } \\
\text { nucleolar } \\
\text { volume } \\
\text { in \% }\end{array}$ \\
\hline & & & & \\
Normal mice & $33.1 \pm 1.7$ & $3.0 \pm 0.1$ & $0.660 \pm 0.024$ & $\begin{array}{l}5.6 \pm 0.4 \\
(8)\end{array}$ \\
& $(8)$ & $(8)$ & $(8)$ & $(8)$ \\
$\begin{array}{l}\text { Obese- } \\
\text { hyperglycemic } \\
\text { mice }\end{array}$ & $35.4 \pm 1.4$ & $3.4 \pm 0.1^{\text {a }}$ & $0.681 \pm 0.043$ \\
$(8)$ & $(9)$ & $(8)$ & $8.8 \pm 0.4 \mathrm{~b}$ \\
& & & & $(10)$ \\
\hline
\end{tabular}

The figures denote mean values \pm S.E.M. The numbers of animals studied are given within parentheses. Comparison between groups of animals: a $P<0.02$; $p P<0.001$.
1 R. E. Stowell, Expl. Cell Res. Suppl. 9, 164 (1963).

2 B. Hellman and B. Petersson, Acta path. microbiol. scand. 50 , $291(1960)$.

3 K. W. TAYlor and D. G. PARRy, J. Endocrin. 39, 457 (1967).

4 C. Helierström, Acta endocrin. Copenh. 45, 122 (1964).

5 B. Petersson, Acta endocrin., Copenh. 53, 480 (1966).

- B. Hellman, Ann. N.Y. Acad. Sci. 131, 541 (1965).

7 R. D. LiLlie, Histopathologic Technic and Practical Histochemistry (The Blakiston Company Inc., New York 1954), p. 31.

8 O. ERänkö, Quantitative Methods in Histology and Microscopic Histochemistry (S. Karger A.G., Basel 1955).

9 This work was supported by grants from the U.S. Public Health Service No. AM-12535, the Swedish Medical Research Council No. $12 x-2288$ and the Medical Faculty in Umeá. 